J. Dairy Sci. 99:3578-3583

http://dx.doi.org/10.3168/jds.2015-10259

(c) 2016, THE AUTHORS. Published by FASS and Elsevier Inc. on behalf

of the American Dairy Science Association ${ }^{\circledR}$. This is an open access article under

the CC BY-NC-ND license (http://creativecommons.org/licenses/by-nc-nd/3.0/).

\title{
Using automated feeders to wean calves fed large amounts of milk according to their ability to eat solid feed
}

\author{
Anne Marie de Passillé and Jeffrey Rushen ${ }^{1}$ \\ Faculty of Land and Food Systems, University of British Columbia, Agassiz, BC, Canada, V0M 1A0
}

\begin{abstract}
Dairy calves weaned off milk at an early age show signs of hunger and can lose weight. We examined whether using automated feeders to wean calves according to individual voluntary solid feed intake reduced the effects of weaning. Female Holstein calves were housed in groups of 5 to 9 . All calves were fed $12 \mathrm{~L} / \mathrm{d}$ milk and ad libitum grain starter and hay from automated feeders immediately after grouping, and were allocated to 3 weaning strategies: (1) early-weaned (EW; $\mathrm{n}=$ 14): weaning began on d 40, and milk allowance gradually decreased until weaning was complete on d 48; (2) late-weaned ( $\mathrm{LW} ; \mathrm{n}=14)$ : weaning began on $\mathrm{d} 80$ and was completed on d 89; (3) weaned by starter intake (WSI; $\mathrm{n}=28$ ): weaning began when calves consumed $200 \mathrm{~g} / \mathrm{d}$ of starter and was completed when the calves consumed 1,400 g/d. Each day, the automated feeders recorded quantities of milk, starter, and hay eaten by all calves, as well as the frequency of visits to the milk feeder; we used unrewarded visit frequency as a sign of hunger. Body weights (BW) were recorded weekly. We estimated daily digestible energy (DE) intake for each calf based on the milk, hay, and starter consumed. Average daily gains (ADG) were expressed as percent of BW. For calves in WSI, weaning began at $54.7 \pm 18.9 \mathrm{~d}$ (mean $\pm \mathrm{SD}$ ) of age, the duration of weaning was 21.1 $\pm 10.6 \mathrm{~d}$, and weaning ended at $75.8 \pm 10.7 \mathrm{~d}$ of age. Both LW and WSI calves had better ADG from wk 3 to 13 than EW calves. Calves in the WSI group drank less milk and ate more starter than LW calves but had similar ADG. During the period of weaning, EW calves made more unrewarded visits to the milk feeder than LW and WSI calves. Three EW calves lost weight during weaning, whereas all LW and WSI calves gained weight. Calves differ greatly in when they begin to eat solid feed and how quickly they increase the intake in
\end{abstract}

Received August 14, 2015.

Accepted January 19, 2016.

${ }^{1}$ Corresponding author: rushenj@mail.ubc.ca response to a decrease in milk allowance. An advantage of automated feeders is that calves can be weaned at variable ages depending on their ability and willingness to eat solid feed, which reduces signs of hunger and improves weight gains during weaning.

Key words: dairy calf, automated feeding, weaning, precision dairying, feeding motivation

\section{INTRODUCTION}

There is growing interest in the use of automated feeders for unweaned dairy calves partly because of potential labor savings (Kung et al., 1997). These feeders also allow greater precision in the measurement and control of individual intakes of liquid and solid feed (Roth et al., 2008; de Passillé and Rushen, 2012), and facilitate feeding unweaned dairy calves more milk or milk replacer, which leads to higher preweaning growth (Khan et al., 2011; Miller-Cushon and DeVries, 2015). There is mounting evidence that high preweaning growth rates are associated, in some way, with increased first-lactation milk yield (Bach, 2012; Soberon et al., 2012). Furthermore, the traditional amounts of milk or replacer fed to unweaned calves ( 8 to $15 \%$ of $\mathrm{BW}$ ) lead to frequent unrewarded visits to a milk feeder or low levels of play behavior, which have been interpreted as signs of hunger (Jensen and Holm, 2003; De Paula Vieira et al., 2008; Borderas et al., 2009; Krachun et al., 2010). Some dairy welfare standards now recommend that milk or replacer be fed to calves at $20 \%$ of BW (Dairy Farmers of Canada, 2009).

A very common method of weaning calves in North America is to wean them at a fixed age, most commonly 6 to 8 wk (Vasseur et al., 2010), but calves weaned at this age can show a growth check at weaning (de Passillé et al., 2011; Eckert et al., 2015; Miller-Cushon and DeVries, 2015). One disadvantage with feeding more milk or milk replacer is that this can reduce the amount of starter that the calves eat (Jensen, 2006; Borderas et al., 2009), reducing growth and increasing signs of hunger during weaning (Borderas et al., 2009). A decrease in growth rates during weaning can erase 
any advantage of feeding more milk or replacer (MillerCushon and DeVries, 2015).

The effects of weaning on growth rates can be overcome by weaning at a later age (de Passillé et al., 2011; Eckert et al., 2015) but this, of course, increases the total amount of milk or replacer that is fed to the calves, which can be an issue when the cost of feeding milk or replacer is high. Interestingly, calves differ greatly in the age that they begin to voluntarily eat large amounts of solid feed (de Passillé and Rushen, 2012), and computer-controlled feeders can be used to adjust the weaning according to each individual calf's willingness to eat starter (Roth et al., 2008; de Passillé and Rushen, 2012). This has been shown to reduce cross-sucking during weaning compared with weaning at a fixed age but the effects on weight gain during weaning are uncertain (Roth et al., 2008, 2009).

Our objectives were to compare weaning according to individual calf starter intake with weaning both at a fixed earlier age (d 48) and a fixed later age (d 89) on feed and energy intakes, weight gains, and behavior during and after weaning. We examined whether this method of weaning would reduce the age at which calves were weaned and the amount of milk used during the milk-feeding period but improve weight gains and reduced behavioral signs of hunger during weaning.

\section{MATERIALS AND METHODS}

\section{Animals and Housing}

We used 56 female Holstein calves (birth weight = $40.50 \pm 4.48 \mathrm{~kg}$; mean $\pm \mathrm{SD}$ ), born at the University of British Columbia (UBC) Dairy Education and Research Centre over a 1-yr period. The calves were born in individual calving pens and given $4 \mathrm{~L}$ of colostrum within $6 \mathrm{~h}$ of birth. Blood samples were collected from the jugular vein $24 \mathrm{~h}$ after the first feeding of colostrum, and serum was analyzed using a digital handheld refractometer (Reichert AR 200; Reichert, Depew, $\mathrm{NY}$ ). Only calves having a serum protein level $>5.5 \mathrm{~g} /$ $\mathrm{dL}$ were included.

Calves were moved to individual pens $(2.0 \times 1.1$ $\mathrm{m}$, with sawdust bedding on concrete) within $24 \mathrm{~h}$ of birth, and remained there until d 5 of age. In the individual pens, calves were allowed ad libitum access to pasteurized waste milk from the dairy herd. Calves had continuous access to milk provided in plastic buckets connected by a hose to a nipple, with fresh milk served at around 0900 and $1500 \mathrm{~h}$. No water or starter was provided from d 2 to 4 of age following normal farm practice. At $5 \mathrm{~d}$ of age, while still in individual pens, the calves were disbudded using caustic paste after sedation with xylazine (Vickers et al., 2005).
At 5 to $6 \mathrm{~d}$ of age, the calves were transferred to $7-\times 4.68-\mathrm{m}$ group pens with a sawdust-bedded resting area $(4.47 \times 4.68 \mathrm{~m})$ and plastic-coated expanded metal floors $(2.53 \times 4.68 \mathrm{~m})$ in front of the feeders (Sweeney et al., 2010). They were kept in groups of 5 to 9 individuals. Calves were fed milk and starter from automated feeders, with both feeders controlled by a single computer (CF 1000 CS Combi, DeLaval Inc., Tumba, Sweden). Calves were allowed $12 \mathrm{~L} / \mathrm{d}$ pasteurized milk from the UBC dairy herd (herd averages of $3.97 \%$ fat, $4.10 \%$ protein, $3.30 \%$ lactose from bulk tank samples) at $40^{\circ} \mathrm{C}$ and had ad libitum access to a textured calf starter (90\% DM: $5.04 \%$ fat, $38.5 \%$ starch, $5.86 \%$ water-soluble carbohydrate, $6.8 \%$ crude fiber, $8.56 \% \mathrm{ADF}, 22.4 \% \mathrm{NDF}$, and $20 \% \mathrm{CP}$ on a DM basis, with the main ingredients being $16 \%$ wheat, $14 \%$ barley, $13 \%$ canola meal, $13 \%$ oats, $10 \%$ soy, $10 \%$ corn, and $4 \%$ molasses: Unifeed Ltd., Chilliwack, BC, Canada). Grass hay $(\mathrm{DM}=90.8 \%$; $\mathrm{CP}=15.1 \%$; $\mathrm{NDF}=51.1 \%$; $\mathrm{ADF}=33.6 \%)$ and water were available ad libitum from automated feeders that weighed the intake of each calf at each meal (RIC, Insentec B.V., Marknesse, the Netherlands). Calves were weighed using an electronic scale once a week.

\section{Weaning Treatments}

The calves were allocated to 3 different weaning strategies as follows: (1) early weaned $(\mathbf{E W} ; \mathrm{n}=14)$ : the calves were fed $12 \mathrm{~L} / \mathrm{d}$ of milk from arrival in the group pens until weaning began on $\mathrm{d} 40$, when the milk allowance was gradually reduced until the calves were fully weaned on d 48; (2) late weaned ( $\mathbf{L W} ; \mathrm{n}=14)$ : the calves were fed $12 \mathrm{~L} / \mathrm{d}$ of milk from arrival in the group pens until d 80; milk was gradually reduced until d 89 when no milk was available to the calves; and (3) weaned by starter intake (WSI; $\mathrm{n}=28$ ): weaning began when the calves had consumed an average of $200 \mathrm{~g} / \mathrm{d}$ of starter during the preceding $3 \mathrm{~d}$, and was completed (i.e., milk allowance reduced to zero) when the calves had consumed an average of $1,400 \mathrm{~g} / \mathrm{d}$ of starter during the preceding $3 \mathrm{~d}$. Once a calf began to be weaned, milk allowance was progressively decreased according to when the calf's intake of starter reached certain set intermediate targets. Intermediate targets for starter intakes were calculated so that the calves would progress from the start target to the end target in 4 steps. The calves had intermediate targets of 600 and $1,000 \mathrm{~g} / \mathrm{d}$. Once the calf had reached the target over the preceding $3 \mathrm{~d}$, the milk allowance was reduced by $3 \mathrm{~L} / \mathrm{d}$.

We used a randomized block design. Calves were blocked for birth order and each block of 4 calves contained 1 EW calf, 1 LW calf, and 2 WSI calves. Each 
group pen contained 1 or 2 blocks, depending on calf availability, so calf is the experimental unit. The group pens contained 1 or 2 extra calves that were not on the experiment.

\section{Data and Statistical Analysis}

Each day, the automated feeders recorded the quantities of milk, starter and hay eaten by all the calves, identifying the calves by radio-frequency ID (RFID) ear tags. We estimated daily digestible energy (DE) intake for each individual calf based on analysis of samples of calf starter and hay (Bodycote Testing Group Inc., Lethbridge, AB, Canada). The mean DE content that was calculated from the analyzed chemical constituents was $3.48 \mathrm{Mcal} / \mathrm{kg}$ for starter and $2.40 \mathrm{Mcal} / \mathrm{kg}$ for hay. Milk was estimated to contain $5.59 \mathrm{Mcal} / \mathrm{kg}$ of DE (NRC, 2001). For each calf in the WSI group, we recorded the age on the first day that the milk allowance was reduced and the age on the first day of zero milk allowance. The duration of weaning was calculated by subtracting the first value from the second.

We calculated the mean BW at each weekly weighing for each of the 3 treatments from wk 3 to 14 . We calculated the ADG from wk 3 to 13 . We also calculated the ADG during the actual period of weaning for each calf. We did this by subtracting the last weight before weaning began (i.e., the first day with a reduced milk allowance) from the first weight after weaning was complete (i.e., the first day with a zero milk allowance). Because calves were weaned at different ages, we expressed this last measure as a percent of initial BW (\% BW).

We calculated overall intakes of milk, starter, hay, and DE from wk 3 to 13 . In addition, we calculated the daily intakes of milk, starter, hay, and DE during the actual period of weaning for each calf. Because calves were weaned at different ages, we expressed these measures as a percent of initial BW (\% BW). We also calculated the mean daily number of unrewarded visits (when no milk was obtained) that each calf made to the milk feeder during the week before weaning began, during the period of weaning, and during the first and second weeks after weaning was completed.

Inspection of the distribution of values did not reveal any marked departures from normality, except for the distribution of the frequency of unrewarded visits to the milk feeder, which was positively skewed. We therefore used a logarithmic transformation for this variable.

Because of occasional technical issues with the feeding and weighing equipment, some BW values were missing on some days. Because of these missing values, the number of calves with complete data varied from week to week, and a number of calves did not have complete data for all weeks. Therefore, we tested the treatment effects separately at each week and in each period relative to weaning. All statistical tests were analyzed using PROC GLM of SAS (SAS Institute Inc., Cary, NC), with weaning treatment as main effect and group as a random effect. To reduce the number of statistical tests, the significance of the difference in BW between weaning treatments was tested in wk 3, $6,8,10,12$, and 13 . To test the treatment effects on BW in wk 4 to 13 , we included the BW in wk 3 as a covariate, and we included mean age as a covariate when testing the effect of treatment on the frequency of visits to the milk feeder. We included group identity in the model as a random factor but the effects of group were never significant. Therefore, we present the least squares means (LSM) of all variables with group excluded. One exception concerned the frequency of visits to the milk feeder, where the effect of group was often significant, and therefore we present the results with group included as a main factor.

\section{RESULTS}

For calves in WSI, weaning began (i.e., the first decrease in milk allowance) at $54.7 \pm 18.9 \mathrm{~d}($ mean \pm SD) of age (range 23-82 d), the duration of weaning was $21.1 \pm 10.6 \mathrm{~d}$ (range 7-49 d), and weaning ended (the first day with no milk) at $75.8 \pm 10.7 \mathrm{~d}$ of age (range 58-94 d).

In wk 10, EW calves were lighter than both LW and WSI calves $(P<0.05$; Table 1$)$. We detected a trend $(P$ $<0.10)$ for a difference in BW in wk 8, with EW calves being the lightest, LW calves being the heaviest, and WSI calves being intermediate (Table 1). We detected trends $(P<0.10)$ for differences in BW in wk 12, with WSI calves being heavier than EW or LW calves (Table 1). Average daily gains from wk 3 to 13 differed among treatments $(P=0.05)$. The EW calves had lower $(P<$ $0.05) \mathrm{ADG}(1.56 \pm 0.08 \%$ of BW) compared with LW calves $(1.85 \pm 0.09 \%$ of BW) and WSI calves (1.80 \pm $0.06 \%$ of BW), with no significant difference between these latter groups $(P>0.10)$.

From wk 3 to 13, EW calves drank less milk and ate more starter than LW calves, with WSI calves having intermediate values (Table 2). Treatment groups did not differ significantly in hay intake or total intake of DE (Table 2).

During the actual period of weaning for each calf, treatment groups differed in the frequency of visits to the milk feeder $(P=0.05)$, with EW calves making more visits than LW or WSI calves (Figure 1). The difference between EW and LW calves continued for the week following the end of weaning but the difference between EW and WSI calves was only a tendency $(P$ $=0.09)$ at that time. In the second week after weaning 


\section{- Early 口Late $⿴ 囗 十$ Starter}

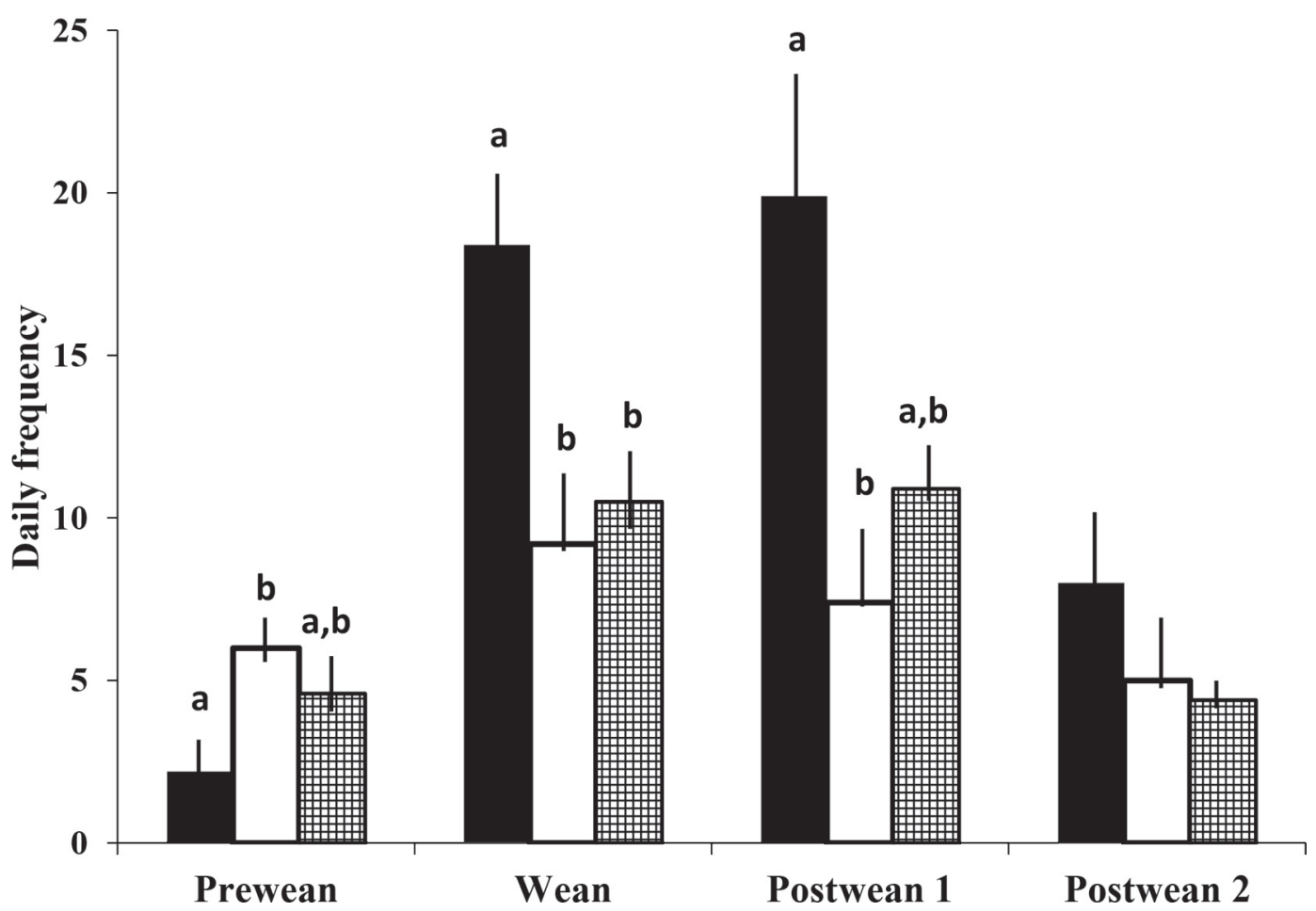

Figure 1. Mean $( \pm \mathrm{SE})$ daily frequency of unrewarded visits (i.e., when no milk was obtained) to the milk feeder during the week before weaning began (Prewean), during the period of weaning (Wean), during the first week after weaning was completed (Postwean 1), and during the second week after weaning was completed (Postwean 2), for calves weaned early or late or weaned according to starter intakes. Bars with different letters $(\mathrm{a}, \mathrm{b})$ differed within each week $(P<0.05)$.

was complete, we detected no treatment effect on the number of visits to the milk feeder $(P>0.10)$.

Between the last weight before weaning commenced and the first weight taken after weaning had finished, ADG $(\%$ of initial BW) was different $(P<0.001)$ among treatments. Three EW calves lost weight during this period, whereas all LW and WSI calves gained weight. During this period of actual weaning (from the first day that milk allowance was decreased to the last

Table 1. Body weights (mean $\pm \mathrm{SE}, \mathrm{kg}$ ) of calves weaned early, late, or by starter intake at each week of age

\begin{tabular}{lcccr}
\hline Week & Early & Late & Starter intake & $P$-value \\
\hline 3 & $53.6 \pm 1.8$ & $50.6 \pm 2.0$ & $52.4 \pm 1.3$ & $>0.10^{1}$ \\
6 & $68.1 \pm 1.4$ & $69.3 \pm 1.6$ & $68.3 \pm 1.0$ & $>0.10^{2}$ \\
8 & $73.4 \pm 2.3^{\mathrm{a}}$ & $82.1 \pm 2.6^{\mathrm{b}}$ & $77.3 \pm 1.6^{\mathrm{ab}}$ & $0.06^{3}$ \\
10 & $84.5 \pm 2.4^{\mathrm{a}}$ & $94.9 \pm 2.6^{\mathrm{b}}$ & $90.6 \pm 1.6^{\mathrm{b}}$ & $0.01^{1}$ \\
12 & $100.2 \pm 2.9^{\mathrm{a}}$ & $106.6 \pm 3.3^{\mathrm{a}}$ & $108.0 \pm 2.1^{\mathrm{b}}$ & $0.07^{1}$ \\
13 & $108.2 \pm 2.8^{\mathrm{a}}$ & $115.9 \pm 3.1^{\mathrm{ab}}$ & $115.2 \pm 2.0^{\mathrm{b}}$ & $0.09^{1}$ \\
\hline
\end{tabular}

$\overline{\mathrm{a}, \mathrm{b}}$ Means within a row with different superscripts are significantly different $(P<0.05)$.

${ }^{1} \mathrm{df}=2,48$.

${ }^{2} \mathrm{df}=2,42$

${ }^{3} \mathrm{df}=2,44$. day with milk), the ADG for EW calves was lower (0.26 $\pm 0.14 \%$ of $\mathrm{BW})$ than that for LW calves $(1.17 \pm 0.17 \%$ of BW; $P<0.001)$ and WSI calves $(1.31 \pm 0.11 \%$ of BW; $P<0.001)$. The difference between the latter 2 treatments was not significant $(P>0.10)$. The actual ADG during weaning for the 3 treatments were $0.15 \pm$ $0.10 \mathrm{~kg}(\mathrm{EW}), 1.21 \pm 0.12 \mathrm{~kg}(\mathrm{LW})$, and $0.96 \pm 0.07$ $\mathrm{kg}$ (WSI).

During the actual period of weaning for each individual calf (from the first day that milk allowance was decreased to the last day with milk), treatment groups

Table 2. Overall intakes (mean $\pm \mathrm{SE}$ ) of milk, starter, hay, and digestible energy (DE) from wk 3 to 13 of life for calves weaned early, late, or by starter intake

\begin{tabular}{lcccc}
\hline Intake & Early & Late & Starter intake & $P$-value \\
\hline Milk (kg) & $267.4 \pm 28.4^{\mathrm{a}}$ & $595.9 \pm 30.7^{\mathrm{b}}$ & $463.1 \pm 20.1^{\mathrm{c}}$ & $<0.001^{1}$ \\
Starter (kg) & $122.3 \pm 12.2^{\mathrm{a}}$ & $42.9 \pm 13.2^{\mathrm{b}}$ & $78.5 \pm 8.6^{\mathrm{c}}$ & $<0.001^{1}$ \\
Hay (kg) & $24.6 \pm 4.1$ & $19.6 \pm 4.4$ & $21.7 \pm 2.8$ & $>0.10^{2}$ \\
DE (Mcal) & $592.6 \pm 31.1$ & $569.6 \pm 33.6$ & $591.5 \pm 22.0$ & $>0.10^{1}$ \\
\hline
\end{tabular}

\footnotetext{
${ }^{\mathrm{a}-\mathrm{c}}$ Means within a row with different superscripts are significantly different $(P<0.05)$.

${ }^{1} \mathrm{df}=2,51$.

${ }^{2} \mathrm{df}=2,49$.
} 
did not differ $(P>0.10)$ in hay intake (expressed as $\%$ of BW). There was a tendency $(P=0.06)$ for $\mathrm{LW}$ calves to drink less milk relative to BW $(4.60 \pm 0.42 \%$ of BW) compared with both $\mathrm{EW}(7.59 \pm 0.42 \% \mathrm{BW})$ and WSI calves $(6.67 \pm 0.28 \%$ of BW). During the actual period of weaning for each individual calf, EW calves ate less starter $(0.45 \pm 0.18 \%$ of $\mathrm{BW})$ than $\mathrm{LW}$ calves $(1.41 \pm 0.18 \%$ of BW; $P<0.001)$ or WSI calves $(1.11 \pm 0.12 \%$ of BW; $P<0.001)$. These differences in intakes resulted in a tendency $(P=0.06)$ for EW calves to have lower DE intakes $(6.82 \pm 0.62 \%$ of $\mathrm{BW})$ than LW calves $(8.63 \pm 0.62 \%$ of $\mathrm{BW} ; P=0.04)$ and WSI calves $(8.48 \pm 0.40 \%$ of $\mathrm{BW} ; P=0.03)$.

\section{DISCUSSION}

Our results show that using automated feeders to gradually wean calves off milk by adjusting the milk allowance according to each individual calf's voluntary intake of starter resulted in the same weight gains as later weaning (at 12 to 13 wk of age) but reduced the average age of weaning somewhat: the duration of milk feeding phase was reduced by an average of 13 to $14 \mathrm{~d}$ but up to $31 \mathrm{~d}$ for some calves. This method of weaning reduced the amount of milk consumed but increased the amount of starter consumed up to the time that weaning was completed for all animals compared with the later weaning. This reduction in weaning age was achieved with no decrease in BW or weight gain. The lack of difference in the number of unrewarded visits to the milk feeder suggests that the levels of feeding motivation (or hunger) were similar for LW and WSI during the period of weaning. When the cost of feeding milk is high compared with the cost of feeding starter, weaning calves according to intakes of solid feed may provide an economic advantage to producers over later weaning. These results support previous research by showing the advantages of weaning using this method (Roth et al., 2008). The method of weaning can affect development of the gastrointestinal tract (Eckert et al., 2015) and such effects of this method of weaning deserve to be investigated.

Interestingly, when calves were weaned according to their intakes of solid feed, the age at which weaning was completed varied among calves. The earliest calves were fully weaned around 8 wk and the last calves at $13 \mathrm{wk}$. This shows the extent that calves differ in their willingness or ability to eat solid feed (de Passillé and Rushen, 2012). As yet, we do not know the basis of these differences; for example, whether they result from differences in the development of the gastrointestinal tract, or differences in calves' taste preferences, or in the extent that the calves learn to recognize a new food source (Miller-Cushon and DeVries, 2015). This emphasizes the importance of better understanding the feeding behavior of calves (Miller-Cushon and DeVries, 2015). The large individual differences may result from the fact that there has been little selection of calves based on their ability to eat solid feed.

It is not uncommon for producers to adjust the age at which weaning begins according to how much starter the calves eat (Greenwood et al., 1997). However, in most cases, the duration of weaning is fixed. Previously, we found that calves differed not only in the age that they began to eat significant amounts of starter but also in the speed at which they were able to increase starter intakes in response to a decrease in milk allowance (de Passillé et al., 2011). These parameters are related in that calves that begin to eat starter at an earlier age require a longer period to increase their intake in order to finish being weaned (de Passillé and Rushen, 2012). Thus, in the current experiment, we also adjusted the speed of the decrease in milk allowance, and the duration of weaning varied greatly between calves ( 7 to 49 d). The optimum parameters to begin and end weaning, as well as the speed with which milk allowance is reduced, need to be better understood in order to fully profit from this method of weaning.

Many dairy farmers in North America wean their calves off milk at 6 to 8 wk of age (Vasseur et al., 2010; Eckert et al., 2015), whereas in Europe, later weaning seems to be more common (Roth et al., 2008). Our results support previous results (de Passillé et al., 2011) in showing that weaning at the earlier age (6 to $8 \mathrm{wk}$ ) leads to a large increase in unrewarded visits to the milk feeder, which has been suggested as showing increased feeding motivation and perhaps hunger (Jensen and Holm, 2003; De Paula Vieira et al., 2008), an interpretation supported by the finding that the frequency of visits is negatively correlated with energy intake (de Passillé et al., 2011). As expected, this earlier weaning greatly reduced the amount of milk the calves drank and increased their intake of starter, but our results suggest that this was a less efficient method because the earlier weaning also resulted in a growth check at the time of weaning, with the resulting lower BW being maintained for at least the next 6 to $8 \mathrm{wk}$. We found a similar difference in BW at 19 to 20 wk of age, but the increased variability between calves resulted in a lack of statistical significance. Therefore, we do not really know how long after weaning this BW advantage of later weaning or weaning by starter intake remained. The extent to which the higher BW achieved before weaning are maintained after weaning depends on how the calves are fed after weaning; clearly more attention needs to be paid to adapting postweaning diets to 
maintain the advantages of higher preweaning weight gains (Khan et al., 2011; Miller-Cushon and DeVries, 2015).

\section{CONCLUSIONS}

Delaying weaning dairy calves off milk until they are 12 to 13 wk old results in better BW gains and reduced signs of hunger during weaning compared with weaning them at 6 to $8 \mathrm{wk}$. This is achieved by an increase in the amount of milk consumed and a reduction in the amount of starter eaten. However, using automated feeders to adjust the milk allowance of each individual calf to its voluntary consumption of starter results in an intermediate weaning age, with reduced consumption of milk and increased consumption of starter but similar weight gains compared with weaning at 12 to 13 wk. The ability to adjust weaning age for each individual calf is one advantage with automated feeders, which can facilitate the feeding of larger amounts of milk or replacer, and this method of weaning can help maintain the higher BW achieved.

\section{ACKNOWLEDGMENTS}

This study was funded by Agriculture and Agri-Food Canada (AAFC; Ottawa, ON, Canada) and Dairy Farmers of Canada (Ottawa, ON, Canada) as part of the Dairy Science Cluster initiative, as well as by the Natural Sciences and Engineering Research Council of Canada. We thank Gosia Zdanowicz (Agriculture and Agri-Food Canada, Agassiz, BC, Canada) and the staff of the University of British Columbia dairy barn (Agassiz, BC, Canada) for their invaluable help.

\section{REFERENCES}

Bach, A. 2012. Ruminant nutrition symposium: Optimizing performance of the offspring: Nourishing and managing the dam and postnatal calf for optimal lactation, reproduction, and immunity. J. Anim. Sci. 90:1835-1845.

Borderas, T. F., A. M. B. de Passillé, and J. Rushen. 2009. Feeding behavior of calves fed small or large amounts of milk. J. Dairy Sci. 92:2843-2852.

Dairy Farmers of Canada. 2009. Code of Practice for the Care and Handling of Dairy Cattle. Dairy Farmers of Canada, Ottawa, ON, Canada. de Passillé, A. M., T. F. Borderas, and J. Rushen. 2011. Weaning age of calves fed a high milk allowance by automated feeders: Effects on feed, water, and energy intake, behavioral signs of hunger, and weight gains. J. Dairy Sci. 94:1401-1408.

de Passillé, A. M., and J. Rushen. 2012. Adjusting the weaning age of calves fed by automated feeders according to individual intakes of solid feed. J. Dairy Sci. 95:5292-5298.

De Paula Vieira, A., V. Guesdon, A. M. de Passillé, M. A. G. von Keyserlingk, and D. M. Weary. 2008. Behavioural indicators of hunger in dairy calves. Appl. Anim. Behav. Sci. 109:180-189.

Eckert, E., H. E. Brown, K. E. Leslie, T. J. DeVries, and M. A. Steele. 2015. Weaning age affects growth, feed intake, gastrointestinal development, and behavior in Holstein calves fed an elevated plane of nutrition during the preweaning stage. J. Dairy Sci. 98:6315-6326.

Greenwood, R. H., J. L. Morrill, and E. C. Titgemeyer. 1997. Using dry feed intake as a percentage of initial body weight as a weaning criterion. J. Dairy Sci. 80:2542-2546.

Jensen, M. B. 2006. Computer-controlled milk feeding of group-housed calves: The effect of milk allowance and weaning type. J. Dairy Sci. 89:201-206.

Jensen, M. B., and L. Holm. 2003. The effect of milk flow rate and milk allowance on feeding related behaviour in dairy calves fed by computer controlled milk feeders. Appl. Anim. Behav. Sci. 82:87-100.

Khan, M. A., D. M. Weary, and M. A. G. von Keyserlingk. 2011. Invited review: Effects of milk ration on solid feed intake, weaning, and performance in dairy heifers. J. Dairy Sci. 94:1071-1081.

Krachun, C., J. Rushen, and A. M. de Passillé. 2010. Play behaviour in dairy calves is reduced by weaning and by a low energy intake. Appl. Anim. Behav. Sci. 122:71-76.

Kung, L., Jr., S. Demarco, L. N. Siebenson, E. Joyner, G. F. W. Haenlein, and R. M. Morris. 1997. An evaluation of two management systems for rearing calves fed milk replacer. J. Dairy Sci. 80:2529-2533.

Miller-Cushon, E. K., and T. J. DeVries. 2015. Invited review: Development and expression of dairy calf feeding behaviour. Can. J. Anim. Sci. 95:1-10.

NRC. 2001. Nutrient Requirements of Dairy Cattle. 7th rev. ed. Natl. Acad. Sci., Washington, DC.

Roth, B. A., E. Hillmann, M. Stauffacher, and N. M. Keil. 2008. Improved weaning reduces cross-sucking and may improve weight gain in dairy calves. Appl. Anim. Behav. Sci. 111:251-261.

Roth, B. A., N. M. Keil, L. Gygax, and E. Hillmann. 2009. Influence of weaning method on health status and rumen development in dairy calves. J. Dairy Sci. 92:645-656.

Soberon, F., E. Raffrenato, R. W. Everett, and M. E. Van Amburgh. 2012. Preweaning milk replacer intake and effects on long-term productivity of dairy calves. J. Dairy Sci. 95:783-793.

Sweeney, B. C., J. Rushen, D. M. Weary, and A. M. de Passillé. 2010. Duration of weaning, starter intake, and weight gain of dairy calves fed large amounts of milk. J. Dairy Sci. 93:148-152.

Vasseur, E., F. Borderas, R. I. Cue, D. Lefebvre, D. Pellerin, J. Rushen, K. M. Wade, and A. M. de Passillé. 2010. A survey of dairy calf management practices in Canada that affect animal welfare. J. Dairy Sci. 93:1307-1315.

Vickers, K. J., L. Niel, L. M. Kiehlbauch, and D. M. Weary. 2005. Calf response to caustic paste and hot-iron dehorning using sedation with and without local anesthetic. J. Dairy Sci. 88:1454-1459. 